\title{
Increasing Brand Awareness of Sunshine Children Centre by Highlighting its Unique Selling Points in a Promotional Video
}

\author{
Stephanie Sutanto \\ Herwindy Maria Tedjaatmadja \\ English Department, Faculty of Languages and Literature, Petra Christian University, Siwalankerto 121- \\ 131, Surabaya 60236, INDONESIA \\ E-mails: stephaniesutanto25@gmail.com;windy382@petra.ac.id
}

\begin{abstract}
Sunshine Children Centre, Semarang is an English Course established in 2005 by Sri Mulyani Gondowardono. This course teaches students from young toddlers up until Grade 6. Sunshine Children Centre's main problem is the decreasing number of students due to the changes from offline to online classes and the fact that this course does not have any promotional tool. Therefore, after considering many factors, the best solution is to make a promotional video and upload it to social media platforms such as Instagram. The duration of the video is only a minute as a promotional video should not last longer than two minutes (Klass, 2018). The video highlights all of the three Unique Selling Points (USPs). The first USP is that this course helps students in their homework and give additional assignments. Second, it offers courses for small groups and private students while the last USP is that it accepts students from both regular and immersion curriculum. By having an engaging promotional video, Sunshine Children Centre will expectedly be able to attract new customers and maintain existing students.
\end{abstract}

Keywords: online learning, promotional video, Unique Selling Points

\section{INTRODUCTION}

In 2005, Sri Mulyani Gondowardono or better known as Miss Yani, founded Sunshine Children Centre, Semarang - Central Java. It teaches students from young toddlers to the $6^{\text {th }}$ grade of elementary schools. When the courses were being conducted offline or face-to-face, Sunshine Children Centre provided the place for the students to come, complete with an Air Conditioner (AC) in each class and Wi-Fi connection to support the learning process. Since the beginning of COVID-19 pandemic, the courses turned into online. However, this course still serves its best to help the students in their online schools. There are two assistants who assist the owner in teaching namely Miss Nancy and Miss Agustine. Each assistant has different teaching responsibilities. Miss Nancy teaches small kids (aged 2 to kindergarten), Miss Agustine teaches elementary school students with a regular curriculum whereas Miss Yani teaches elementary school students with an immersion curriculum. During the internship, the writer worked as an assistant to the owner with the main task of preparing devices used for online classes as well as and handling technical issues, for example Wi-Fi connection and video editing for student assignments. In addition, the writer was assigned to prepare material and teach some students through Whats App and Google Meet.

There are two main competitors of the Sunshine Children Center. The first is Competitor 1 (later referred to as C1), an English course (established in 2021) and the second is Competitor 2 (later referred to as $\mathrm{C} 2$ ) which was established in 2017. The two courses only accept regular students, and all classes are in groups. C1 teaches Grade 1 to Grade 12, while C2 only teaches Grade 7 to Grade 12. Between the two courses, C1 is the biggest competitor of the Sunshine Children Center mainly due to the adjacent location. In addition, $\mathrm{C} 1$ has a very wide target market, in which some is the same as that of the Sunshine Children Center. However, what distinguish the Sunshine Children Center from its competitors are that this course accepts regular and immersion students and the fact that this course offers classes in both private and group formats. 
After approximately three months of doing the internship, there were a number of problems encountered. The most important problem to be solved is related to sales and marketing. During the past three months, online classes' announcements were only promoted via posts in the owner's WhatsApp story and word of mouth. Doing a promotion only through WhatsApp stories was not effective and efficient to increase brand awareness because people who could see the story were just the ones who have been acquainted with the owner. There was a decreasing number of students and in the past 3 months, there were no new students registered for the course. Just before the government regulation requires the citizens to stay at home due to the COVID-19 pandemic, Sunshine Children Center had 75 students. After the outbreak, there were only 58 students who stayed to take the online classes.

The absence of an effective and efficient promotional tool that is suitable for the current conditions made the writers choose to solve by making a promotional tool in the form of video to be uploaded to social media. The Unique Selling Points of Sunshine Children Centre will be emphasized in the promotional video. By making a promotional video, more people will know about this course and what makes this place stand out among any other competitors. Other than that, the parents will have a better idea about how online courses work, and they will be more convinced that this course is trustworthy.

There are some principles or theories used in working on the project as they can be used to provide frameworks for this project, namely the promotional video for Sunshine Children Centre. The theories or the principles are about definitions, purposes, and features used in making a promotional video.

\section{Brand and Branding}

To begin with, a brand can be defined as a set of tangible and intangible attributes designed to create awareness and identity, and to build the reputation of a product, service, person, place, or organization (Bonnici, 2015). Branding is a process to ensure the success of a product or service by making people trust that the product or service is better than the other. Branding can reinforce a good reputation, encourage loyalty, assure quality, and convey a perception of greater worth (allowing a product to be priced higher). In addition, branding is a two-way process between the producers and customers (Healey, 2008, pp. 10-14, 26-28). There are six steps of how to do branding for a company (Sodhi, 2006), namely:

1) The company needs to define the business framework.

2) The company must know who its target market is

3) The company must identify its value prepositions

4) The company must understand what products or services it offers

5) The company must create brand graphics and messages to let people know what it is doing

6) The company must develop an integrated marketing plan to make a detailed plan so that all activities will run properly and can produce as much as possible.

There are six reasons why branding is important (Dwight, 2015):

- Branding helps to grow a company's reputation.

- Branding can help a company to win investment.

- Branding can help a company to attract new customers.

- Branding can boost employee pride and satisfaction.

- Branding can help to build trust in the marketplace. 
Sutanto: Increasing Brand Awareness of Sunshine Children Centre by Highlighting its

Unique Selling Points in a Promotional Video

- Branding supports a company's advertising effort.

\section{Brand Awareness}

Brand awareness is the way a brand can be remembered when consumers think about a certain category of a product or service, how easily a name can appear in the customers' minds (Shimp, 2003). Awareness refers to how strongly a brand can be embedded in the customers 'or clients' minds.

\section{Marketing}

According to Kotler (2006, p. 5) marketing is a process of selling and buying goods among the people. It has two goals which attract new customers by giving the promising value and it keeps and grows the current customers by making them happy after using or buying our products. According to Titley (2015, p.178), marketing is not just a promotional or advertising and selling activity. There are three steps that can be taken by a company to carry out the maximum marketing process. First, a company can identify its customers' needs and wants. This includes the product or service needed, the quality people are looking for, and the estimated cost that people are willing to spend to get it. Second, a company should satisfy the customers' needs and wants. A customer must have expectations that can be met by producers. After taking the first stage, a company can think carefully to create a product or service that can satisfy the needs and desires of its customers. Third, a company can create a backup plan to anticipate unexpected things. The world of business is not always predictable, so it is essential for a company to have a backup plan.

\section{Promotion}

Promotion is a communication process of marketers to market targets to explain about a product or service and to persuade the target markets to take a buying action (Kalb, 2002, pp. 181191). According to Martin (2014), every organization has different goals and expectations from the promotional activities they carry out. Some of them are:

- Building brand awareness

- Creating interest

- Providing information

- Stimulating demand

- Differentiating products

- Reinforcing the brand

\section{Promotional Tool}

A promotional tool will inform them about the existence of the products and develop brand awareness (MacKenzie, 2002, pp. 60-62). Belch (2018) categorizes promotional tools into six types:

- Sales Promotion : : coupons, samples

- Publicity/Public relations : sponsorship

- Personal selling : face-to-face communication

- Digital/internet marketing : internet and social media (Instagram, Facebook, etc)

- Direct marketing : direct selling, telemarketing, and direct-response advertising through direct mail, online, various broadcast and print media.

- Advertising : television, radio, magazines, newspaper 
Based on the abovementioned classification, a promotional video is included in Digital or Internet Marketing. The use of the internet is the key to digital marketing to inform the products or services that are sold in the promotional video that was created.

\section{Promotional Video}

Promotional video is a piece of content specifically designed to promote the company's products and services to customers and prospects. The main goal is to give the audience the feel of what the businesses look like. A good promotional video should provide the right portion of information. Giving too much information will make the audience no longer feel curious so that it will minimize the opportunity for the audience to contact the company (Ruby, 2012, p.7). In line with it, a promotional video should not be more than two minutes because people tend to be bored watching a long promotional video (Klass, 2018). Other than that, according to the Instagram's rule and suggestion, it is better to upload a 1-minute video so that the video will not be divided into some sections for the feeds. For the Instagram Story, a 1-minute video will be divided into four sections. Another important detail to consider is the selection of the background and text colors. Using the right contrast is essential. Using the wrong colors can decrease the readability drastically as it will quickly tire the reader's eyes. Black text on a white background has the highest readability whereas black and yellow or orange is another combination which usually has a high readability.

\section{Unique Selling Points}

Unique Selling Point (USP) is a very important element that differs a company's products or services from any other competitors. Unique Selling Point will help a company to stand out among its competitors. It is very important to tell the customers about its USP because it will help the customers to easily remember about its products or services and identify its products among the other competitors (Kettle, 2017). To find out more about its USP, a survey was conducted.

\section{METHOD}

The ten respondents were mothers aged 24-30 years. These ten respondents were selected based on the different level of interaction with the course (e.g. some asked a lot of questions to the course while some did not) and how long they have been taking the course.

The main objective of this survey was to find out whether the target market prefers promotional tools in the form of a video or photo and to find out what social media platforms are used most often. A semi-structured interview was conducted via WhatsApp chat. A semi-structured interview usually has a guideline or framework of the main questions but also allows new ideas or questions to be brought up during the interview. The four main questions were in Indonesian language since most parents felt more comfortable using Indonesian.

\section{FINDING AND DISCUSSION}

\section{Result of the Survey}

The first question is "Do respondents think that video promotion tools are more attractive than photos?" The finding has revealed that $80 \%$ of the respondents said that a promotional tool in the form of a video is indeed more attractive than a photo; half of which further explained that 
Sutanto: Increasing Brand Awareness of Sunshine Children Centre by Highlighting its Unique Selling Points in a Promotional Video

to promote a service, a video is the best choice because it can provide a clear picture such as a demonstration of the service being offered.

The second question is "What social media platforms do parents and children use the most?" Again, the majority $(80 \%)$ of the respondents answered that Instagram is the social media platform they use the most, $10 \%$ preferred Facebook, while the remaining chose YouTube. The purpose of this question is to find out and determine the platform to upload the promotional video.

The third question is "Between Indonesian and English, which one is the respondent more comfortable using?" Since all of the respondents are more comfortable using Indonesian, the writer decided to use Indonesian voiceover with English subtitles.

The last question is "How much time do you usually spend on social media?" Almost all respondents answered that they spent more than 3 hours a day on social media.

\section{The Finding on the Unique Selling Points}

There are three Unique Selling Points (USPs) of the Sunshine Children Centre. The first USP is Sunshine Children Center helps students to complete their homework from school and give additional assignments. The second USP is Sunshine Children Center offers to teach the students in groups and privately depending on the students' needs while the last USP is Sunshine Children Center accepts students from both regular and immersion curriculum.

\section{The Explanation of Each Scene in the Promotional Video}

The logo that appears at the beginning of the promotional video is an identity for the Sunshine Children Centre. As a logo is an important aspect for a brand because it represents the face of the company (Bonnici, 2015), the logo clearly explains the name of the course as the sun represents the word "Sunshine". The hands that hold the sun represent this course that will take care of the students such as helping the students in finishing their school homework and teaching them about the upcoming lessons at their own schools. The logo and the brand's name were displayed twice (in the beginning and the end) in the promotional video to make the customers remember the name of this course. This way, the customers can remember the brand more easily (Shimp, 2003).

There are three unique selling points highlighted in the promotional video. Highlighting the unique selling points is crucial to help the target market easily identify the course among its competitors (Kettle, 2017). The first USP is Sunshine Children Centre accepts students from both Immersion and Regular classes. It is a strength for this course because the competitors only accept regular students. Immersion class students use English in all their subjects in school such as Science, Mathematics, Faith, Language and Arts. Regular class students only use English for the English lesson only. In the video, this point was emphasized through voice over and subtitles.

The second USP is that this course offers online courses in small groups and private so that parents and students can choose which one is more suitable for the students. Some parents feel that private tutoring can maximize the child's concentration, while some feel that interacting with friends is important for their children while learning. Online classes in the form of groups will be held according to the school and class of the students, for example, all 5th graders from the same school will be in the same schedule.

The third USP is that this course not only helps students in completing their homework but also provides additional assignments to prepare them for the next subject at school. Additional assignments are needed so that students can prepare themselves as best as possible for the next lesson. 
The logos of platforms used for the online classes were displayed. This course provides several platforms namely Google Meet, Zoom, and WhatsApp. The students can choose which platform to use for their online classes so that they can feel more comfortable.

In the last two scenes, there is a Call to Action sentence: "Jangan ragu untuk menghubungi kami dan segeralah mendaftar, kami tunggu!" (Don't hesitate to contact us and sign up right away! We're waiting for you!). It is a piece of content intended to induce the target audience to perform a specific act, in this case, to immediately register for an online course.

The last scene is the contact information of Sunshine Children Centre and the name of the owner. First, there is the WhatsApp number of the owner. Second, the phone number of this course. Those two numbers were given so that the target audience can choose the method of communication because some people like to text while some others like to talk. There is also a sentence which can be considered a Call to Action to reassure the target audience to contact this course immediately. The total duration of the video is 1 minute, following the Instagram's rule and suggestion and Klass' theory (2018) stating that a promotional video should not last for more than two minutes.

After uploading the promotional video to the social media, the response obtained is quite good. There were several parents who asked for more information about this online course. Some of them have already registered for the new semester next year. Promotional videos will be uploaded several times to social media to get maximum results.

\section{CONCLUSION}

To solve Sunshine Children Centre's sales and marketing problem, a promotional video was made because it contains visuals and audio to provide a better overview about how the online courses are running. The promotional video highlighted the three Unique Selling Points of this English course. After the shooting and editing process was done, the promotional video was uploaded its Instagram account (both Instagram feeds and story) to attract more people and to increase the brand awareness. Since almost everyone uses social media actively, it is expected that Sunshine Children Center's potential target markets can easily get more information from the promotional video.

\section{REFERENCES}

Belch, G.E., Belch, M.A. (2018). Advertising \& Promotion: an integrated marketing communication perspective (1 $11^{\text {th }}$ ed). New York, NY: McGraw-Hill Education.

Bonnici, T. S. (2015). Brand and branding. Wiley encyclopedia of management. Retrieved from https://www.academia.edu/39884936/Brand_and_Branding.

Dwight, H. (2015). Six Reasons Why Branding is Important for All Businesses. Retrieved from https://www.talentedladiesclub.com/articles/six-reasons-why-branding-is-importantfor-all-businesses/

Healey, M. (2008). What is Branding?.Singapore: Page One Publishing Pte Ltd.

Kalb, I.S. (2002). e-Marketing: What went wrong and how to do it right. California: K\&amp;A Press.

Kettle, M. (2017). The Importance of Having a Unique Selling Point (USP). Retrieved December 03, 2018, from https://www.melkettle.com/2017/05/importance-unique-selling-point/

Klass, Y. (2018). Learn What A Promotional Video Definition Is and Why It's Important. Retrieved December 03, 2018, from https://slide.ly/promo/blog/learn-what-apromotional-video-definition-is-and-why-its-important/ 
Sutanto: Increasing Brand Awareness of Sunshine Children Centre by Highlighting its

Unique Selling Points in a Promotional Video

Kotler, P., \& Armstrong, G. (2006). Principles of marketing. New Jersey, United States: Pearson Prentice Hall

MacKenzie, I. (2002). English for Business Studies: A course for Business Studies and Economics Students. United Kingdom: Cambridge University Press

Martin. (2014, August 8). Cleverism. Promotion in Four P's. Retrieved from https://www.cleverism.com/promotion-four-ps-marketing-mix/

Ruby, L. (2012). The Beginner's Guide to Video Marketing. Retrieved June 30, 2018, from http://rubymarketingsystems.com/pdfs/beginners-guide-to-videomarketing

Shimp, T.A. (2003). Periklanan Promosi dan Aspek Tambahan Komunikasi Pemasaran Terpadu. Jakarta: Erlangga.

Sodhi, R. (2006). 6 Practical steps to bringing your brand to life. Retrieved August 9, 2020, from http://rsodhi.blogspot.com/

Titley, B. (2015). Complete business studies for Cambridge IGCSE \& 0 Level. London: Oxford University. 